Int. J. Morphol.,

33(1):194-203, 2015.

\title{
The Effect of Visfatin on Inflammatory Reaction in Uterus of LPS-Induced Rats
}

\author{
Efecto de Visfatina en la Reacción Inflamatoria en el Útero de Ratas Inducidas por LPS
}

Zhi Yang*; Ke Xiao; Wei Wang; Juan Tang; Peng-Peng Sun; Ke-Mei Peng \& Hui Song

YANG, Z.; XIAO, K.; WANG, W.; TANG, J.; SUN, P. P.; PENG, K. M. \& SONG, H. The effect of visfatin on inflammatory reaction in uterus of LPS-induced rats. Int. J. Morphol., 33(1):194-203, 2015.

SUMMARY: The present study was to investigate the effects of visfatin on the morphological structure and function of the rat uterus during inflammation. The expression and distribution of visfatin, morphological structure, eosinophils (EOS), myeloperoxidase (MPO) and cytokines in the uterus of the LPS-induced rat were studied using hematoxylin-eosin staining (HE), immunohistochemical methods, western blots and enzyme-linked immunosorbent assay (ELISA). The present study showed that visfatin positive cells dispersed widely in the uterus, and strong positive staining was observed mainly in the cell cytoplasm. Compared with saline group, in visfatin group, more uterine glands were found, EOS increased, and the difference was significant $(\mathrm{P}<0.05)$, MPO reduced, and the difference was significant $(\mathrm{P}<0.01)$. In addition, visfatin was able to increase the secretion of IL-1 $1 \beta$, IL-6, and TNF- $\alpha(\mathrm{P}<0.01)$. Compared with LPS group, in vifatin+LPS group, the uterine glands of the lamina propria increased, the myometrium became thinner, the number of EOS and MPO reduced obviously, but the difference was not significant $(\mathrm{P}>0.05)$, and after LPS stimulated body, visfatin decrease the level of IL-1 $\beta$, IL-6, TNF- $\alpha(\mathrm{P}<0.01)$. The above results suggest that visfatin could affect the morphological structure of rat uterus; Visfatin could modulate the inflammatory response in rats' uterus by regulating the quantity of inflammatory cells, such as EOS and MPO, and the level of inflammatory cytokines, such as IL-1 $\beta$, IL-6, TNF- $\alpha$.

KEY WORDS: Visfatin; LPS-induced rat; Uterus; Inflammation; Cytokine.

\section{INTRODUCTION}

The uterus is an important reproductive organ of humans and animals and it has its own set of immune mechanism to defend against pathogen infection. Uterus infection not only reduces the reproductive performance of animals, but also increases the animal's healthcare costs (Turner et al., 2012). Uterine inflammation is an important disease of the reproductive system, which can delay pregnancy and lead to infertility, so more research is needed on the immune system and factors involved in uterine inflammation to prevent and treat uterine diseases (Mor \& Cardenas, 2010). Lipopolysaccharides (LPS) can stimulate inflammatory mediators of cells, which is a key factor in inducing inflammation. In the uterus, LPS can cause an extensive and strong inflammatory response and endometrial injury, and induce cytokine release in endometrial epithelial cells, stromal cells, endothelial cells, neutrophils, macrophages and stromal cells (Dauphinee \& Karsan, 2006).

Visfatin, a recently discovered adipokine, expresses itself in the ovary and the fetal membranes. It is correlated with intrauterine growth, gestational diabetes and polycystic ovary syndrome (Chan et al., 2007; Lewandowski et al., 2007; Malamitsi-Puchner et al., 2007). Previous studies showed that visfatin participated in inflammatory responses and played a role in intestinal mucosal immunity induced by LPS in rats (Dahl et al., 2012). Extracellular visfatin has been shown to increase inflammatory cytokines, such as IL$1 \beta$, IL- 6 and TNF- $\alpha$. However, the expression and distribution of visfatin in rat uterus and its role in the uterine inflammation induced by LPS have not been reported. The present study was conducted to illustrate the role of the visfatin in the rat uterine inflammation and explain the relationship between visfatin and uterus.

\section{MATERIAL AND METHOD}

Sample collection and processing. Eight-week-old Wistar rats were randomly divided into 4 groups (6 rats in each group) including saline group, visfatin group, LPS group and visfatin+LPS group. Rats in each group received a tail 
vein injection as follows: (1) rats in saline group and LPS group both received $0.5 \mathrm{ml} 0.9 \% \mathrm{NaCl}$ solution injection each day; (2) rats in visfatin group and visfatin+LPS group both received the injection of visfatin $(10 \mu \mathrm{g} / \mathrm{kg})$ each day. One week later, LPS (O111: B4, sigma) $(2.5 \mathrm{mg} / \mathrm{kg}$ body weight) was injected into rats in LPS group and visfatin+LPS group. All the animals were sacrificed at $6 \mathrm{~h}$ after the injection of LPS. Uterus tissue specimens were quickly removed, part of the tissue was fixed with $4 \%$ paraformaldehyde and was subsequently embedded in paraffin. Uterus samples were allocated for histopathological and immunohistochemical investigations. Stained sections were analyzed under a light microscope (BX51; Olympus, Tokyo, Japan). Other uterus tissues were kept at $-80^{\circ} \mathrm{C}$ in the refrigerator, the MPO of the tissue was tested by western blot and the inflammatory cytokines of the tissue was tested by ELISA. Data were then analysed using the Quantity One (Bio-Rad) software.

HE Staining . H\&E staining was performed by dewaxing the paraffin sections, and then the slides were mounted with coverslips and analyzed under a light microscope.

Immunohistochemical Staining. The deparaffined sections were washed in PBS solution for $5 \mathrm{~min}$, and then placed in $0.01 \mathrm{M}$ citrate buffer solution ( $\mathrm{pH}$ 6.0) for $20 \mathrm{~min}$ for antigen retrieval. After cooling to room temperature, the samples were incubated with $3 \% \mathrm{H}_{2} \mathrm{O}_{2}$ for 20 min, washed with PBS and then were blocked by $5 \%$ normal goat serum for 20 min. Subsequently, the samples were incubated with primary antibody (rabbit anti-rat visfatin, 1:100, Bioss Inc, Beijing, China or rabbit anti-rat MPO, 1:100, Boster Inc, Wuhan, China) or with PBS instead of antibody (as negative control), overnight at $4^{\circ} \mathrm{C}$. After washing three times with PBS, the samples were incubated with goat anti-rabbit (Bioss, Beijing, China) for $20 \mathrm{~min}$ at $37^{\circ} \mathrm{C}$. After washing with PBS, the sections were detected by microscopy.

Eosinophils Staining. The deparaffined sections were stained with hematoxylin for $4 \mathrm{~min}$ and washed with distilled water for $10 \mathrm{~s}$. Then, the sections were immersed in $1 \%$ hydrochloric acid for $10 \mathrm{~s}$, before being washed with running water for $15 \mathrm{~min}$. Subsequently, the sections were incubated with chromotropic acid for $40 \mathrm{~min}$ at room temperature, and washed with distilled water for $10 \mathrm{~s}$. Finally, the samples were dehydrated with a graded ethanol series, cleared in xylene and mounted with a coverslip.

Western Blot. Taken from the refrigerator kept at $-80^{\circ} \mathrm{C}$, the uterus tissue samples were dissolved in lysis buffer and extracted protein. The protein concentrations were determined by BioRad-Assay. The samples were separated at equal protein concentration and transferred to nitrocellulose membranes. Then the membranes were blocked to prevent non-specific protein binding and incubated with rabbit anti-rat MPO (1:200) overnight at $4^{\circ} \mathrm{C}$. Subsequently, the membranes were incubated with a horseradish peroxidase (HRP) (1:50000, Boster Inc, Wuhan, China). Quantification was performed using the software Quantity One (Bio-Rad).

ELISA. Concentrations of IL- $1 \beta$, IL- 6 and TNF- $\alpha$ in uterus samples were determined using commercially available $\mathrm{Ab}$ and protein standards from $R \& D$ Systems according to manufacturer's instructions. Absorption was determined with a MicroplateReader at $450 \mathrm{~nm}$.

Statistical analysis. All data were expressed as Mean \pm SD values $(\mathrm{n}=6)$. Statistical analyses were performed by using SPSS 17.0 software and GraphPad Prism v5.0 software. Differences were considered significant if $\mathrm{P}<0.05$.

\section{RESULTS}

Localization and expression of visfatin positive cells in rat uterus. Immunohistochemical results showed no visfatin expression in negative control sections (Fig. 1A). The visfatin expression mostly showed brownish yellow staining in the cytoplasm (Fig. 1C). Visfatin positive cells distributed widely in the uterus, and Visfatin positive signals were observed in the endometrium, myometrium and perimetrium (Fig. 1B), especially in the glands of endometrium (Fig. 1C) and mucosal epithelium (Fig. 1D). There was also positive expression in the connective tissue of lamina propria of endometrium; the cells were fusiform, numerous, and stained deeper (Fig. 1C). Positive signals were also observed in the cytoplasm of circular muscle of myometrium with scattered distribution, and the cells, mostly fusiform or pleomorphic in shape, were stained deeper.

The effect of visfatin on uterine organization structure in LPS-induced rats. After HE staining, changes of organizational structure (mainly focused on endometrial structure and myometrial thickness) in the rat uteruses were found in different experimental treatment groups under the microscope.

Macrophages, spindle cells, polygonal cells and blood cells were observed in the lamina propria. The blood cells were round, their cytoplasm was stained light pink, and most nucleuses appeared in two leaves (Fig. 2A). The number of uterine glands in endometrial lamina propria and the thickness of myometrium increased in visfatin group, compared to those in saline group (Fig. 2B, Table I). 


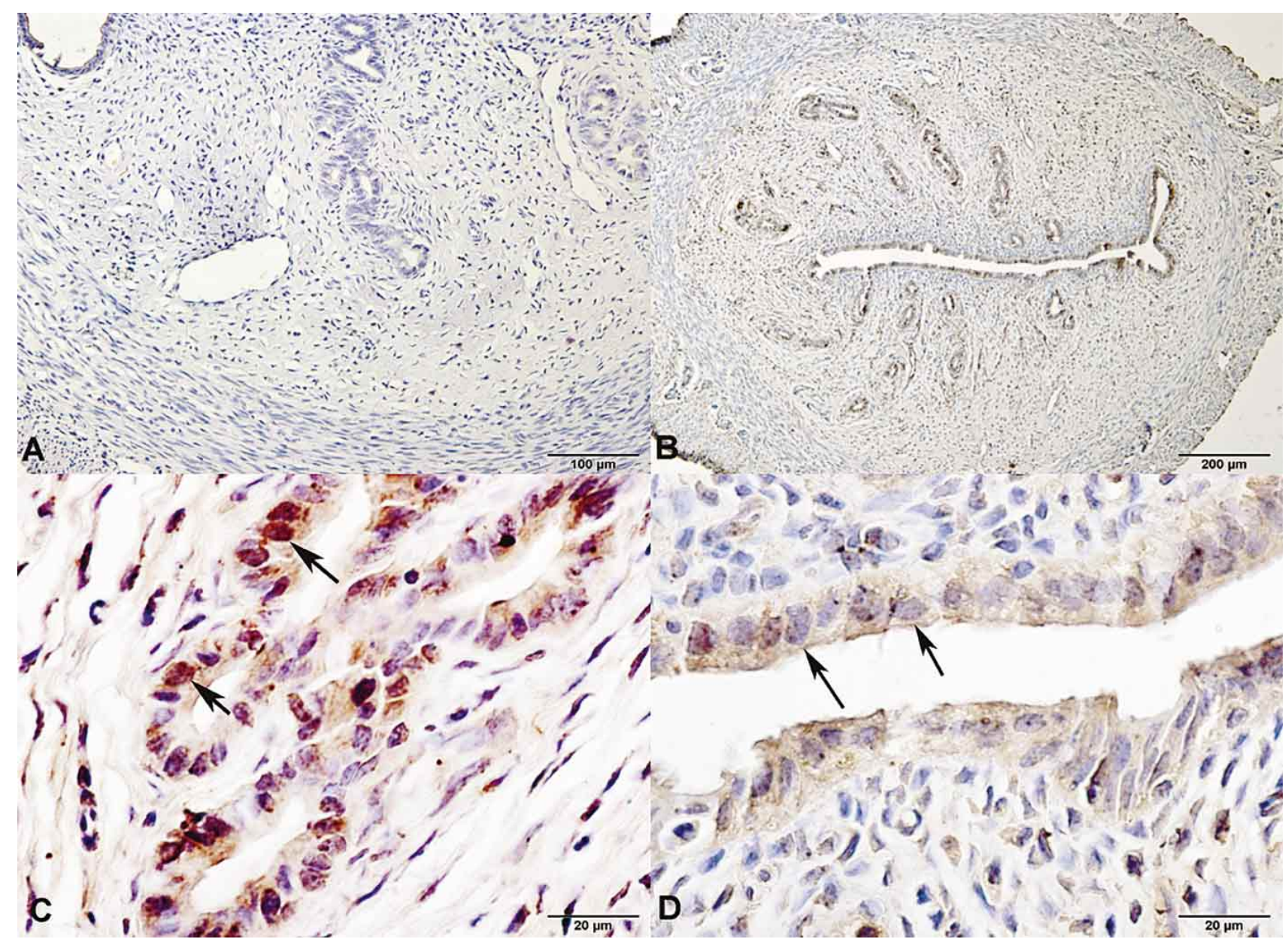

Fig. 1. Visfatin expressed in uterus. (A) Negative control shows no positive product. (B) Visfatin positive product in saline group. (C) Visfatin positive cells shown in uterine glands. (D) Endometrium has many visfatin positive cells. The arrow points to visfatin positive cells.

Table I. The thickness of endometrium and myometrium in different groups. In the same row, values with different letter superscripts mean significant difference $(\mathrm{P}<0.05)$, while with the same and no letter superscripts mean no significant difference $(\mathrm{P}>0.05)$.

\begin{tabular}{lcccc}
\hline Thickness $(\boldsymbol{\mu m})$ & Saline group & Visfatin group & LPS group & Visfatin+LPS group \\
\hline Endometrium & $439.46 \pm 49.97 \mathrm{ab}$ & $491.35 \pm 44.86 \mathrm{a}$ & $378.91 \pm 28.15 \mathrm{c}$ & $413.10 \pm 33.96 \mathrm{bc}$ \\
Myometrium & $342.07 \pm 16.69 \mathrm{c}$ & $398.79 \pm 8.01 \mathrm{~b}$ & $481.60 \pm 18.10 \mathrm{a}$ & $185.23 \pm 8.92 \mathrm{~d}$ \\
\hline
\end{tabular}

Uterus organization structure changed significantly after LPS treatment. Most of the endometrial epithelial cells began to slough and the endometrium became thinner (Table I). A greater number of blood cells emerged in the endometrial lamina propria, and the number of fibroblasts and the thickness of myometrium increased (Fig. 2C, Table I). Compared with LPS group, the number of the uterine glands of lamina propria and macrophage increased, and uterine gland secretions and the thickness of myometrium decreased in visfatin + LPS group (Fig. 2D, Table I).
The changes of EOS in different experimental treatment groups. Microscopic observations showed that after EOS staining, EOS mainly distributed in the lamina propria of the uterus. A large number of EOS was also observed in circular muscle and EOS scattered in longitudinal muscle of myometrium. The cytoplasm was stained bright red and the nucleus was stained blue, and the number of EOS varied among different groups. Statistical analysis suggested the number of EOS was higher in visfatin group than in saline group (Fig. 3B, 3A 


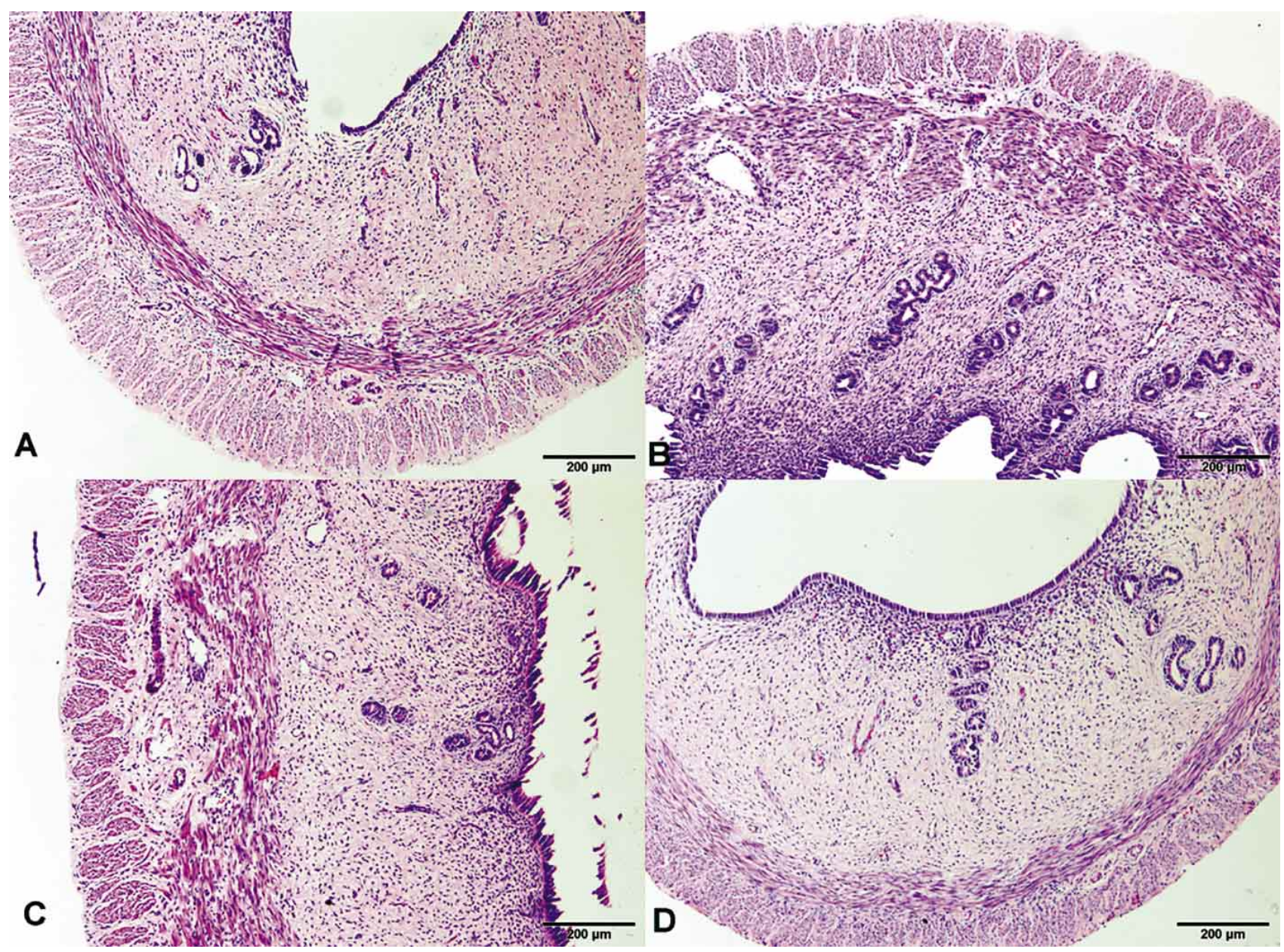

Fig. 2. The effects of visfatin on uterine organization structure (A) Normal organization structure in saline group. (B) In visfatin group, the number of uterine glands and the thickness of myometrium was higher than in saline group. (C) The endometrial epithelial cells began to fall off and the endometrium became thinner in LPS group. (D) In visfatin + LPS group, the number of uterine glands was higher than in LPS group.

and $3 \mathrm{E}, \mathrm{P}<0.05)$. The number of EOS was fewer in LPS group than in saline group (Fig. 3C and 3A, P>0.05). In visfatin + LPS group, the number of EOS was fewer than in LPS group (Fig. 3D, 3C and 3E, P>0.05). Specific changes in the results were shown in Fig. 3E.

The changes of myeloperoxidase (MPO) in different treatment groups. Immunohistochemical results showed no MPO expression in negative control group (Fig. 4B). The positive products of MPO distributed widely in endometrium, myometrium and perimetrium. MPO expressed abundantly in the epithelium of endometrium and uterine glands (Fig. 4C). Scattered positive signals were also observed in the circular muscle of myometrium. MPO expression appeared as brownish yellow and was seen in the nucleus and cytoplasm, and most MPO positive cells appeared in fusiform or pleomorphic shapes.
Western blot results showed that MPO was reduced in visfatin group compared to the saline group (Fig. 4G and $4 \mathrm{H}, \mathrm{P}<0.01$,), and MPO was reduced in LPS group compared to the saline group (Fig. $4 \mathrm{G}$ and $4 \mathrm{H}, \mathrm{P}>0.05$ ). The results also showed that MPO was decreased in visfatin + LPS group compared to LPS group (P>0.05) (Fig. 4G and $4 \mathrm{H}, \mathrm{P}>0.05$ ).

The changes of some inflammatory cytokine in different treatment groups. The level of inflammatory cytokine, IL$1 \beta, \mathrm{IL}-6$, and TNF- $\alpha$ in uterus was detected with ELISA. By the data analysis, we could see that the secretion of IL$1 \beta$, IL-6, and TNF- $\alpha$ in visfatin group was increased compared to saline group (Fig. 5A, 5B and 5C, $\mathrm{P}<0.01$ ). But after LPS stimulated body, the level of IL-1 $\beta$, IL-6, TNF- $\alpha$ was decreased compared to LPS group (Fig. 5A, $5 \mathrm{~B}$ and $5 \mathrm{C}, \mathrm{P}<0.01)$. 

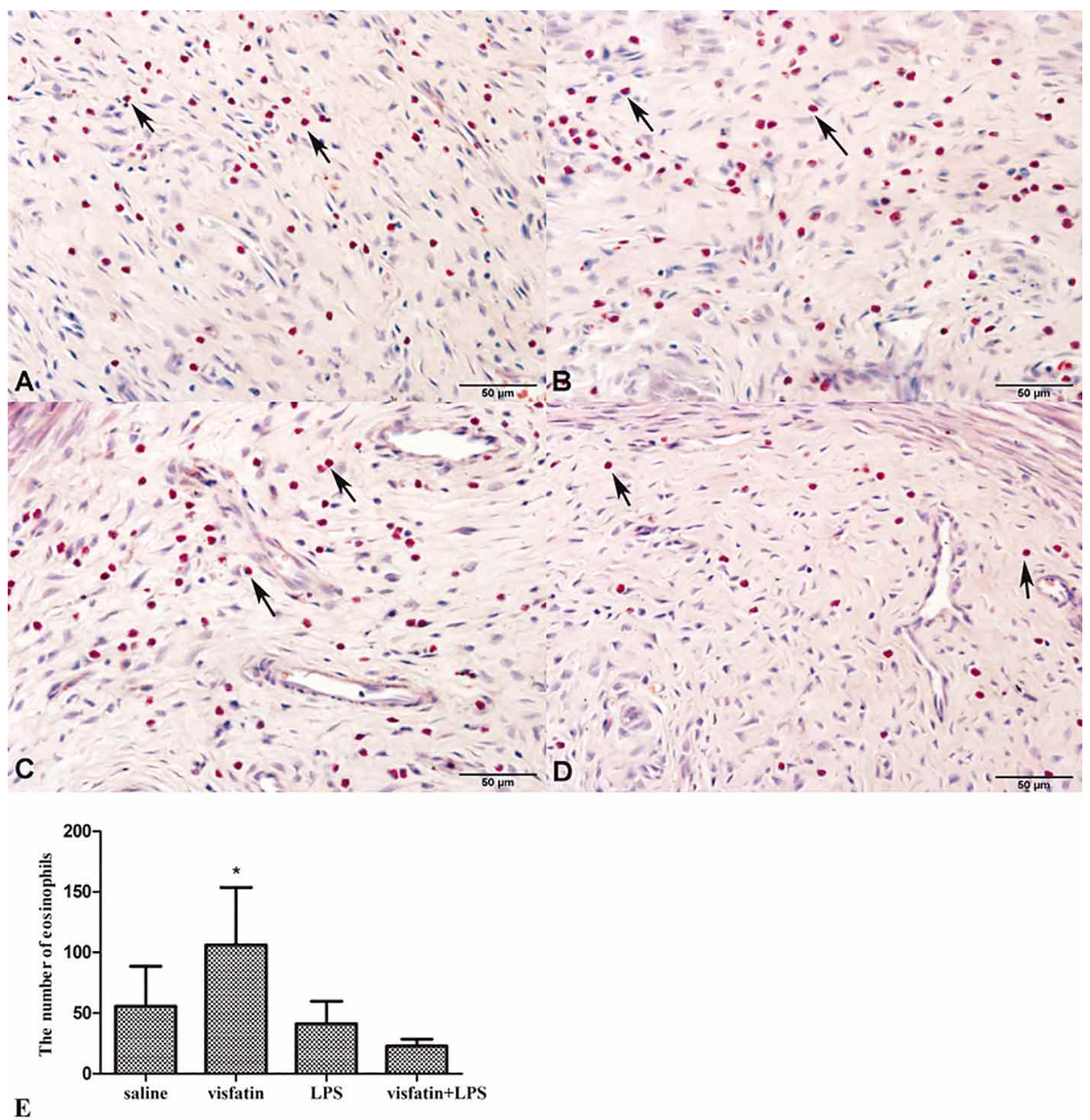

Fig. 3. The expression of EOS in different groups. (A) Saline group (B) In Visfatin group, the number of EOS was higher than in saline group $(\mathrm{P}<0.05)(\mathrm{C})$ In LPS group, the number of EOS was lower than in saline group $(\mathrm{P}>0.05)(\mathrm{D})$ Visfatin+LPS group, the number of EOS was lower than in saline group $(\mathrm{P}>0.05)$. The arrow points to EOS. (E) The number of EOS in different groups.

\section{DISCUSSION}

The localization of visfatin in rat uterus. As an adipocytokine, visfatin has many biological activities, participates in a variety of physiological responses and has the similar structure to that of the pre-B cell colonyenhancing factor (PBEF) which is found in lymphocytes. Besides visceral adipose tissue, liver, uterus, pancreas, 


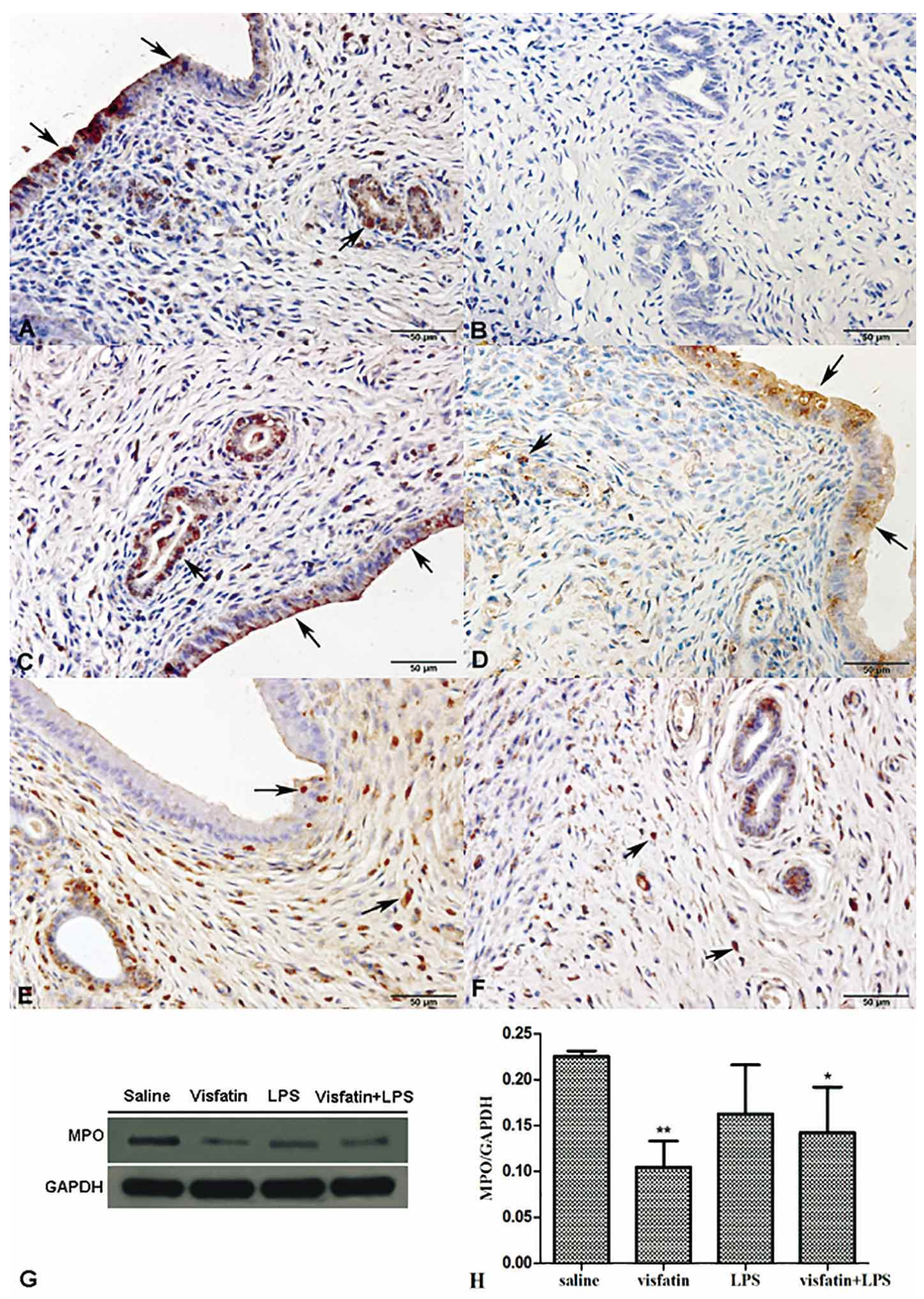

Fig. 4. The expression of MPO in different groups. (A) MPO expression in uterus of saline group. (B) No MPO in negative control group. (C) MPO in saline group. (D) MPO in visfatin group. (E) MPO in LPS group. (F) MPO in visfatin + LPS group. Arrow indicates MPO expression. $(\mathrm{G})$ Western blot shows MPO in different groups. $(\mathrm{H})$ MPO expression was reduced in visfatin group compared to the saline group $(\mathrm{P}<0.01)$, MPO expression was reduced in visfatin+LPS group compared to the saline group $(\mathrm{P}<0.05) . *=\mathrm{P}<0.05 ; * *=\mathrm{P}<0.01$. 

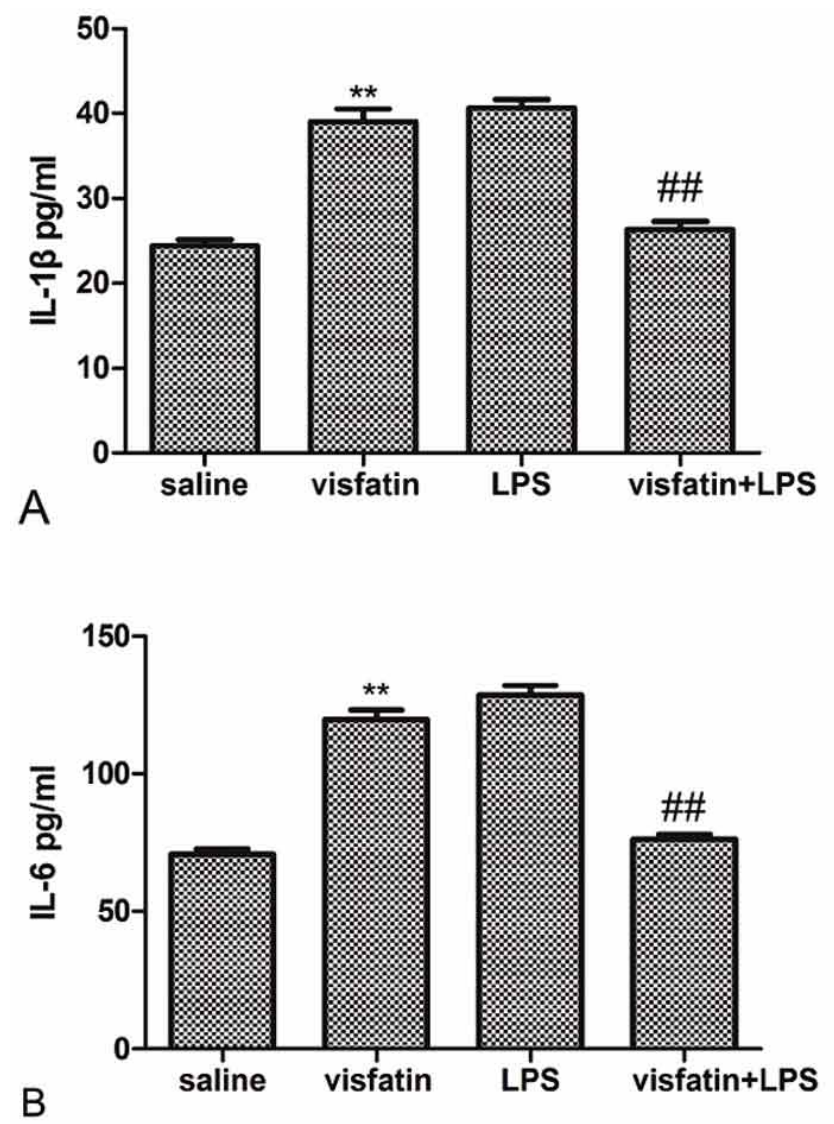

muscle tissue, fetal membranes, small intestine, bone marrow, lymphocytes, and heart, also secrete visfatin (Ognjanovic \& Bryant-Greenwood, 2002; Sethi \& VidalPuig, 2005). Visfatin immunoreactive cells are mainly distributed in the uterine glands of endometrial lamina propria, which suggests that visfatin may be involved in the secretion of the uterine glands. Epithelial cells of the endometrium also expressed visfatin, which means visfatin may participate in the uterus mucosal immune barrier and play a role in defending against pathogens infection. Most visfatin positive cells in the lamina propria were macrophages and fibroblasts (fusiform or polygonal). In accordance with the previous studies, macrophages were the main source of visfatin and visfatin caused inflammation in synovial fibroblasts (Curat et al., 2006). Visfatin positive cells also distributed in circular muscle and longitudinal muscle of the myometrium, which is in accordance with the previous reports that visfatin can also be secreted in muscle tissues (Ognjanovic \& Bryant-Greenwood; Sethi \& VidalPuig), showing that visfatin may participate in the formation of smooth muscle.

The effects of visfatin on rat uterine organization structure Previous research showed that the uterus had a se-
Fig. 5. Measurement of Inflammatory factors by ELISA. (A) IL-1b; (B) IL-6; (C) TNF-a. Compared with saline group, $* *=\mathrm{P}<0.01$; Compared with LPS group, \#\#= $\mathrm{P}<0.01$.

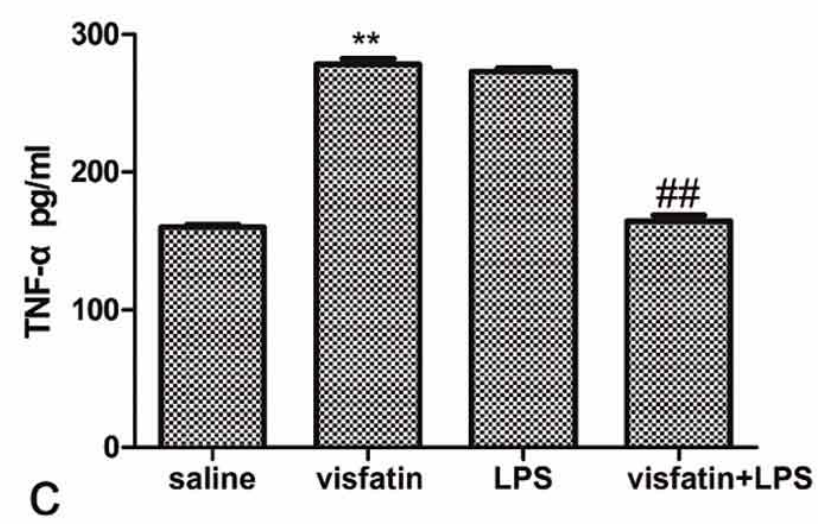

ries of structural changes in different periods and conditions (Garry et al., 2010). Our experiment found more uterine glands of endometrial lamina propria in visfatin group than in saline group, which further confirms that visfatin participates in the secretion of uterine glands. Some studies reported that visfatin stimulated the myocardial cells and vascular smooth muscle leading to their hypertrophy and hyperplasia (Turner et al., 2011). So the thickness of myometrium in visfatin group increasing maybe due to that the injected recombinant visfatin protein which made visfatin increase, which stimulated hypertrophy and hyperplasia of the smooth muscle, but the specific mechanism needs further research.

LPS is an important pathogenic agent. LPS treatment in endometrial cells can increase the expression of $\mathrm{IL}-1 \beta$, IL-6 and induce inflammation (Cronin et al., 2012). In LPS group, rat uterine mucosa had a wide range of cracks, fell off and the cell gaps became larger. The epithelium cells of endometrium had vacuoles and karyopyknosis, and intercellular gaps became bigger. This is in accordance with the theory that LPS can cause strong inflammation and destruction of endometrial cells (Wong et al., 2000). In addition, we also found that uterine smooth muscle became 
thicker in LPS group, and it may be because LPS enhanced the proliferation and activity of uterine smooth muscle cells. The result accords with the research that LPS stimulated vascular smooth muscle to produce TNF and IL-1 and it regulated the expression of proto-oncogenes to promote the proliferation of vascular smooth muscle cells (Yang et al., 2005; Curtis et al., 2013). The thickness of uterine smooth muscle decreased in visfain + LPS group compared with that in LPS group. This suggests that visfatin can inhibit the proliferation of LPS-induced uterine smooth muscle. Hyperplasia was observed in smooth muscle tissue in visfatin group and LPS group, but we found the activity of smooth muscle cells and DNA proliferation weakened with the addition of recombinant visfatin protein into LPS group. Those results suggest that visfatin modulates the LPS-induced uterine inflammation.

The impact of visfatin on the EOS in rat uterus. EOS is an important nonspecific immune cell when uterus immunological stress happens. Previous studies showed that EOS mainly distributed in endometrium and myometrium of the rat uterus and had the functions of transporting antigens and secreting inflammatory cytokine (Wall et al., 2013; Linde \& DiMaio, 2011). Some studies found that visfatin got involved in the inflammatory response as an adipocytokine. In a previous study, Moschen et al. (2007) found that the recombinant visfatin activated white blood cells and induced the generation of cytokines. In the present study, the quantity of EOS is most in visfatin group in rat uterus, which confirmed that visfatin can participate in the uterus inflammation reaction by regulating the quantity of EOS.

As one of the most important active ingredients of endotoxin, LPS can activate neutrophils, monocytes and macrophages, and mediate the body's inflammatory responses (Phillipson \& Kubes, 2011; Martinez et al., 2008; Boots et al., 2012). In the present study, the quantity of EOS was lesser in LPS group than that in saline group. The result suggests that LPS-mediated increase of the number of the white blood cells in immune stress reaction may was mainly caused by the change of neutrophils and monocytes. Most EOS was apoptotic in the process of inflammation, which resulted in the decrease of EOS. Moreover, the number of EOS in the uterus was the least in visfatin + LPS group, which indicated that visfatin aggravated the apoptosis of EOS or inhibited its production.

The impact of visfatin on the neutriphils of rat uterus. Neutrophils play an important role in the body's nonspecific cellular immunity, and neutrophils will be activated and play an anti-inflammatory role when external pathogens infect the uterus (Martinez et al., 2012; Rinaldi et al., 2014). Myeloperoxidase (MPO) is one of the major neutrophil bactericidal proteins involved in the host defense. It is abundant in the azurophilic granules of neutrophils. Only a small amount of MPO is present in some macrophages and monocytes (Kamanna et al., 2013). Cyclic MPO is mainly produced by neutrophils, accounting for $95 \%$ of all the cyclic MPO (Lau \& Baldus, 2006). Thus, MPO is considered a symbol of neutrophils in cytochemistry. In this experiment, the amount of MPO was less in visfatin group as compared with that in saline group, which may be because visfatin inhibited the activation and production of neutrophils. This result indicated that visfatin participated in the response caused by neutrophils. Moreover, the amount of MPO was lower in visfatin+LPS group compared with that in LPS group, which indicated visfatin inhibited the activation of neutrophils or made them go apoptotic. Some studies showed that the level of MPO increased in inflammatory tissues, so MPO activity measurement was used as an index of inflammation (Tiruppathi et al., 2004). Those results further suggest that visfatin plays role in LPS-induced uterine inflammatory response.

Inflammation will happen when LPS stimulates the body. Previous studies have indicated MPO was activated in the lung and the liver of the rat, and reached a plateau $6 \mathrm{~h}$ after the injection of a certain dose of LPS, and then the level reduced after $6 \mathrm{~h}$ (Li et al., 2005). In our study, the rat was killed $6 \mathrm{~h}$ after the injection of LPS, so the level of MPO level was lower in LPS group than that in saline group.

The impact of visfatin on the inflammatory cytokine of rat uterus. Cytokines, such as IL-1 $\beta$, IL- 6 , and TNF- $\alpha$ have close relationship with inflammatory. The level of IL-1 $\beta$, IL6 , and $\mathrm{TNF}-\alpha$ was increased in inflammatory processes, so they are regarded as proinflammatory cytokines. Recent studies have shown that visfatin is also a proinflammatory cytokine in a variety of inflammatory processes. Increased levels of visfatin have also been shown to closely associated with some proinflammatory cytokines such as IL-1, IL-6, and TNF- $\alpha$ (Sun et al., 2013; Teplan et al., 2014). In the present study, we could see that visfatin could up-regulate the level of IL- $1 \beta$, IL- 6 , and TNF- $\alpha$ in rats' uterus treated with visfatin. This result is supported by the previous findings that as an extracellular cytokine, visfatin was able to increase the secretion of IL-1 1 , IL- 6 , and TNF- $\alpha$, especially upregulating circulating IL-6 (Moschen et al.). But after LPS stimulated body, visfatin decrease the level of IL-1 $\beta$, IL-6, and $\mathrm{TNF}-\alpha$ compared to LPS group. The above results suggested that visfatin was involved in inflammatory responses in rats' uterus by regulating the productions of inflammatory cytokines, and visfatin might have a dual regulation in inflammation process. But the mechanism of visfatin regulating the inflammatory process should be taken into consideration. 
In conclusion, Visfatin was participated in the inflammatory responses in rats' uterus by regulating the expression of EOS, MPO, and the level of IL-1 $\beta$, IL-6, and TNF- $\alpha$. Visfatin might have a dual regulation in inflammation process in the uterus, but the mechanism of visfatin regulating the inflammatory process should be taken into consideration.

ACKNOWLEDGEMENTS. This study was supported by National Natural Science Fund Project of China No. 31101776.

YANG, Z.; XIAO, K.; WANG, W.; TANG, J.; SUN, P. P.; PENG, K. M. \& SONG, H. El efecto de visfatina en la reacción inflamatoria en el útero de ratas inducidas por LPS. Int. J. Morphol., 33(1):194-203, 2015.

RESUMEN: El objetivo del presente estudio fue investigar los efectos de la visfatina sobre la estructura morfológica y la función del útero de la rata durante la inflamación. Se estudiaron la expresión y distribución de la visfatina, la estructura morfológica, eosinófilos, mieloperoxidasa y citoquinas en el útero de rata mediante la tinción de H\&E, métodos inmunohistoquímicos, Western blots y ELISA. El estudio mostró que las células visfatina positivas se dispersan ampliamente en el útero, junto a una fuerte tinción positiva, principalmente en el citoplasma de la célula. En comparación con el grupo control, en el grupo visfatina, se encontraron más glándulas uterinas, se observó un aumento de EOS y la diferencia fue significativa $(\mathrm{p}<0,05)$, MPO reducida siendo esta diferencia también significativa $(\mathrm{p}<0,01)$. Además, la visfatina fue capaz de aumentar la secreción de IL-1b, IL-6 y TNF-a $(\mathrm{P}<0,01)$. En comparación con el grupo LPS, visfatina+grupo LPS, las glándulas uterinas de la lámina propia aumentaron, se observó un miometrio más delgado, y número reducido de EOS y MPO, sin embargo, la diferencia no fue significativa ( $>0,05)$. Después de estímulo LPS en el cuerpo, se registró un nivel menor de visfatina en IL-1b, IL-6, TNF-a $(\mathrm{P}<0,01)$. Los resultados anteriores sugieren que visfatina podría afectar a la estructura morfológica del útero de rata. Además, podría modular la respuesta inflamatoria en el útero mediante la regulación de la cantidad de células inflamatorias, tales como EOS y MPO.

PALABRAS CLAVE: Visfatina; Rata inducida con lipopolisacáricos; Útero; Inflamación; Citoquinas.

\section{REFERENCES}

Boots, A. W.; Gerloff, K.; Bartholomé R.; van Berlo, D.; Ledermann, K.; Haenen, G. R.; Bast, A.; van Schooten, F. J.; Albrecht, C. \& Schins, R. P. Neutrophils augment LPSmediated pro-inflammatory signaling in human lung epithelial cells. Biochim. Biophys. Acta, 1823(7):1151-62, 2012.

Chan, T. F.; Chen, Y. L.; Chen, H. H.; Lee, C. H.; Jong, S. B. \& Tsai, E. M. Increased plasma visfatin concentrations in women with polycystic ovary syndrome. Fertil. Steril., 88(2):401-5, 2007.

Cronin, J. G.; Turner, M. L.; Goetze, L.; Bryant, C. E. \& Sheldon, I. M. Toll-like receptor 4 and MYD88-dependent signaling mechanisms of the innate immune system are essential for the response to lipopolysaccharide by epithelial and stromal cells of the bovine endometrium. Biol. Reprod., 86(2):51, 2012.

Curat, C. A.; Wegner, V.; Sengenès, C.; Miranville, A.; Tonus, C.; Busse, R. \& Bouloumié, A. Macrophages in human visceral adipose tissue: increased accumulation in obesity and a source of resistin and visfatin. Diabetologia, 49(4):744-7, 2006.

Curtis, B.; Payne, T. J.; Ash, D. E. \& Mohanty, D. K. Secondary amines containing one aromatic nitro group: preparation, nitrosation, sustained nitric oxide release, and the synergistic effects of released nitric oxide and an arginase inhibitor on vascular smooth muscle cell proliferation. Bioorg. Med. Chem., 21(5):1123-35, 2013.
Dahl, T. B.; Holm, S.; Aukrust, P. \& Halvorsen, B. Visfatin/ NAMPT: a multifaceted molecule with diverse roles in physiology and pathophysiology. Annu. Rev. Nutr., 32:229-43, 2012.

Dauphinee, S. M. \& Karsan, A. Lipopolysaccharide signaling in endothelial cells. Lab. Invest., 86(1):9-22, 2006.

Garry, R.; Hart, R.; Karthigasu, K. A. \& Burke, C. Structural changes in endometrial basal glands during menstruation. BJOG, 117(10):1175-85, 2010.

Kamanna, V.; Ganji, S. \& Kashyap, M. Myeloperoxidase and Atherosclerosis. Curr. Cardiovasc. Risk Rep., 7(2):102-7, 2013.

Lau, D. \& Baldus, S. Myeloperoxidase and its contributory role in inflammatory vascular disease. Pharmacol. Ther., 111(1):1626, 2006.

Lewandowski, K. C.; Stojanovic, N.; Press, M.; Tuck, S. M.; Szosland, K.; Bienkiewicz, M.; Vatish, M.; Lewinski, A.; Prelevic, G. M. \& Randeva, H. S. Elevated serum levels of visfatin in gestational diabetes: a comparative study across various degrees of glucose tolerance. Diabetologia, 50(5):1033-7, 2007.

Li, L.; Bhatia, M.; Zhu, Y. Z.; Zhu, Y. C.; Ramnath, R. D.; Wang, Z. J.; Anuar, F. B.; Whiteman, M.; Salto-Tellez, M. \& Moore, 
P. K. Hydrogen sulfide is a novel mediator of lipopolysaccharide-induced inflammation in the mouse. FASEB J., 19(9):1196-8, 2005.

Linde, E. M. \& DiMaio, D. J. Solitary esophageal leiomyoma with eosinophilic infiltrate: case report and review of the literature. Dis. Esophagus, 24(1):E5-7, 2011.

Malamitsi-Puchner, A.; Briana, D. D.; Boutsikou, M.; Kouskouni, E.; Hassiakos, D. \& Gourgiotis, D. Perinatal circulating visfatin levels in intrauterine growth restriction. Pediatrics, 119(6):e1314-8, 2007.

Martinez, F. O.; Sica, A.; Mantovani, A. \& Locati, M. Macrophage activation and polarization. Front. Biosci., 13:453-61, 2008.

Martinez, N.; Risco, C. A.; Lima, F. S.; Bisinotto, R. S.; Greco, L. F.; Ribeiro, E. S.; Maunsell, F.; Galvão, K. \& Santos, J. E. Evaluation of peripartal calcium status, energetic profile, and neutrophil function in dairy cows at low or high risk of developing uterine disease. J. Dairy Sci., 95(12):7158-72, 2012.

Mor, G. \& Cardenas, I. The immune system in pregnancy: a unique complexity. Am. J. Reprod. Immunol., 63(6):425-33, 2010.

Moschen, A. R.; Kaser, A.; Enrich, B.; Mosheimer, B.; Theurl, M.; Niederegger, H. \& Tilg, H. Visfatin, an adipocytokine with proinflammatory and immunomodulating properties. $J$. Immunol., 178(3):1748-58, 2007.

Ognjanovic, S. \& Bryant-Greenwood, G. D. Pre-B-cell colonyenhancing factor, a novel cytokine of human fetal membranes. Am. J. Obstet. Gynecol., 187(4):1051-8, 2002.

Phillipson, M. \& Kubes, P. The neutrophil in vascular inflammation. Nat. Med., 17(11):1381-90, 2011.

Rinaldi, S. F.; Catalano, R. D.; Wade, J.; Rossi, A. G. \& Norman, J. E. Decidual neutrophil infiltration is not required for preterm birth in a mouse model of infection-induced preterm labor. J. Immunol., 192(5):2315-25, 2014.

Sethi, J. K. \& Vidal-Puig, A. Visfatin: the missing link between intra- $\alpha$ bdominal obesity and diabetes? Trends Mol. Med., 11(8):344-7, 2005.

Sun, Z.; Lei, H. \& Zhang, Z. Pre-B cell colony enhancing factor (PBEF), a cytokine with multiple physiological functions. Cytokine Growth Factor Rev., 24(5):433-42, 2013.

Teplan, Jr. V.; Senolt, L.; Hulejova, H.; Teplan, V.; Stollova, M. \& Gurlich, R. Early changes in serum visfatin after abdominal surgery: a new pro-inflammatory marker in diagnosis? Biomed. Pap. Med. Fac. Univ. Palacky Olomouc Czech Repub., 158, 2014. (In press).
Tiruppathi, C.; Naqvi, T.; Wu, Y.; Vogel, S. M.; Minshall, R. D. \& Malik, A. B. Albumin mediates the transcytosis of myeloperoxidase by means of caveolae in endothelial cells. Proc. Natl. Acad. Sci. USA, 101(20):7699-704, 2004.

Turner, M. L.; Healey, G. D. \& Sheldon, I. M. Immunity and inflammation in the uterus. Reprod. Domest. Anim., 47(Suppl. 4):402-9, 2012.

Turner, N. A.; Das, A.; O'Regan, D. J.; Ball, S. G. \& Porter, K. E. Human cardiac fibroblasts express ICAM-1, E-selectin and $\mathrm{CXC}$ chemokines in response to proinflammatory cytokine stimulation. Int. J. Biochem. Cell Biol., 43(10):1450-8, 2011.

Wall, E. H.; Hewitt, S. C.; Liu, L.; del Rio, R.; Case, L. K.; Lin, C. Y.; Korach, K. S. \& Teuscher, C. Genetic control of estrogen-regulated transcriptional and cellular responses in mouse uterus. FASEB J., 27(5):1874-86, 2013.

Wong, P. M.; Chugn, S. W. \& Sultzer, B. M. Genes, receptors, signals and responses to lipopolysaccharide endotoxin. Scand. J. Immunol., 51(2):123-7, 2000.

Yang, X.; Coriolan, D.; Murthy, V.; Schultz, K.; Golenbock, D. T \&, Beasley, D. Proinflammatory phenotype of vascular smooth muscle cells: role of efficient Toll-like receptor 4 signaling. Am. J. Physiol. Heart Circ. Physiol., 289(3):H1069-76, 2005.

\section{Correspondence to:}

Hui Song

Ke-Mei Peng

College of Veterinary Medicine

Huazhong Agricultural University

Lion Street 1, Hongshan District

Wuhan 430070

CHINA

\section{Email: songh2007@mail.hzau.edu.cn kmpeng@sohu.com}

Received: 03-11-2014

Accepted: 02-12-2014 